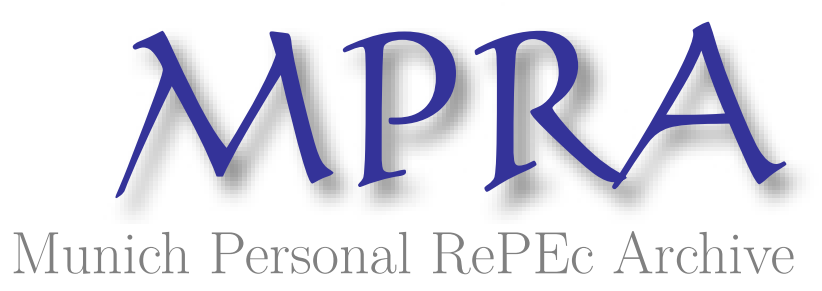

\title{
Interactions Between Federal and Provincial Cash Transfer Programs: The Effect of the Canada Emergency Response Benefit on Provincial Income Assistance Eligibility and Benefits
}

Petit, Gillian and Tedds, Lindsay M.

School of Public Policy, University of Calgary

18 May 2021

Online at https://mpra.ub.uni-muenchen.de/107895/

MPRA Paper No. 107895, posted 22 May 2021 00:33 UTC 


\title{
Interactions Between Federal and Provincial Cash Transfer Programs: The Effect of the Canada Emergency Response Benefit on Provincial Income Assistance Eligibility and Benefits
}

\author{
Gillian Petit and Lindsay M. Tedds ${ }^{*}$ \\ School of Public Policy, University of Calgary
}

Draft Date: May 18, 2021

\begin{abstract}
The Canada Emergency Response Benefit (CERB) was a temporary cash transfer program for workers who had reduced earnings due to the COVID-19 pandemic over the period of March 15 and October 2, 2020. While the benefits of getting the CERB out the door as quickly as possible should not be understated, the speed with which the CERB was rolled out led to the program being implemented without clear objectives, the nature of the benefit not defined, and no time for detailed negotiations within and across governments as to how the CERB would be treated not only related to eligibility for other programs, but also the benefit levels delivered by these programs. There are three possible ways in which the CERB could be treated by these various programs: as an employment insurance benefit, as working income, or as a benefit payment. Each of these different ways of treating the CERB has different implications for eligibility and for the level of benefit from other government programs. The purpose of this chapter is to examine how the failure to provide a universal definition of the CERB led to it being treated differently, not only across governments, but also differently by various programs within a given government. We will show that what might have appeared to be a minor technical administrative oversight led to confusion by CERB beneficiaries who were also collecting other government benefits over program interaction effects that differed depending on which jurisdiction the CERB beneficiary lived.
\end{abstract}

\footnotetext{
${ }^{1}$ Gillian Petit is a Ph.D. Candidate in the Department of Economics and a Research Associate in the School of Public Policy, University of Calgary. She can be contacted at gillian.schafer@ucalgary.ca. Dr. Lindsay M. Tedds is an Associate Professor in the Department of Economics and Scientific Director, Fiscal and Economic Policy, School of Public Policy, University of Calgary. She can be contacted at lindsay.tedds1@ucalgary.ca. We gratefully acknowledge funding from the Government of British Columbia (spcs46008190052) that helped support this research. We would like to thank the editors of this volume, Molly Harrington, Assistant Deputy Minister, Research, Innovation, and Policy Division, Social Development and Poverty Reduction, Government of British Columbia, and Robert Bruce, Executive Director, Research Branch, Research, Innovation, and Policy Division, Social Development and Poverty Reduction, Government of British Columbia, for their helpful comments and information as we were preparing this chapter. All inferences, opinions, conclusions, errors, or omissions are those of the authors.
} 


\section{Introduction}

Within Canada, both the federal government and provincial/territorial governments administer and deliver income and social supports. Sometimes these income and social support programs interact with others in ways that affect eligibility and benefit levels. In this chapter, we look at one such interaction that arose during the COVID-19 pandemic: the interaction between provincial/territorial income assistance programs (sometimes called "welfare") and the federal Canada Emergency Response Benefit (CERB).

The CERB was an important source income support during COVID-19: it rapidly provided much needed cash transfers for those negatively affected by the pandemic. As impressive as the CERB was, due to its quick roll-out, there were no federal/provincial/territorial agreements in place regarding the program, particularly how provinces and territories should treat the CERB income for the purposes of their other income and support programs. This meant the answer to this question was left up to each provincial/territorial income assistance program and different jurisdictions treated the income from the CERB differently.

To understand how to answer the question of 'what the income was from the CERB' consider the general framework of how various forms of income can be treated with respect to provincial/territorial income assistance programs. For income assistance applicants and recipients, they are only eligible for income assistance if their qualifying, or "non-exempt", income is below an income threshold and, while receiving income assistance, their level of qualifying income then affects their income assistance benefit level. What counts as qualifying income depends on the origin of the income being considered. For example, earned income and benefits from the Canada Pension Plan are included in qualifying income, albeit differentially as we will discuss shortly, whereas income received from the Canada Child Benefit (CCB) is exempted from qualifying income.

The main reason for differentiating amongst various forms of income for eligibility and maintenance of income assistance benefits is primarily because provincial income assistance programs are considered to be 'funders of last resort.' Before accessing income assistance benefits, most other forms of income and wealth should be used first, thereby creating a wall to keep those with other options out of the program. There are some caveats to this, with full exemptions mainly granted for income that is intended to reduce child poverty (e.g., CCB) or partial exemptions granted for income from employment to incentivize labour market participation. The reason income assistance programs allow recipients to earn some amount of employment income without being completely cut off of income assistance is to address a phenomenon known as the 'welfare wall;' the state where many income assistance recipients can end up worse off if they accept paid work because they lose access to income assistance benefits. As noted by Petit and Tedds (2021a), income assistance programs across Canada are designed so that recipients who accept employment are not completely cut off of income assistance. Instead, they have their benefits reduced, usually less than dollar for dollar as they begin to earn income.

What does this mean for the CERB? Had the CERB been designated specifically as akin to a tax benefit program to support low income individuals, like the CCB, the CERB would not have been included in income assistance qualifying income thereby allowing income assistance clients who received the CERB to remain eligible for income assistance and keep their full income 
assistance benefits. ${ }^{2}$ On the other hand, had the CERB been designated specifically as lost earnings, the CERB would have been treated the same as earned income for the purpose of qualifying income in income assistance programs, resulting in a 'partial exemption' of the CERB. That is, for income assistance recipients who received the CERB, they may have remained eligible for income assistance and had their income assistance benefits clawed back by the same amount that usual employment earnings are clawed back. Finally, had the CERB been specifically designated as akin to an employment insurance program, the full amount of the CERB would have been included in qualifying income. Since most income assistance income thresholds are lower than the CERB, the majority of income assistance clients receiving the CERB would have become ineligible for income assistance.

Leaving this technical specification up to each jurisdiction led to different treatments of the CERB for income assistance clients depending on their province/territory of residence, as shown in Figure 1. British Columbia, the Yukon, and the Northwest Territories all fully exempted the CERB for their income assistance clients. Alberta (Alberta Works), Manitoba, Ontario, and Quebec all partially exempted the CERB. Finally, Saskatchewan and the Atlantic provinces all did not exempt the CERB, resulting in the majority of income assistance recipients who collected the CERB becoming ineligible for income assistance. The purpose of this chapter is to consider the implications of this differential treatment.

Figure 1: Treatment of CERB for Income Assistance Recipients Across Canada

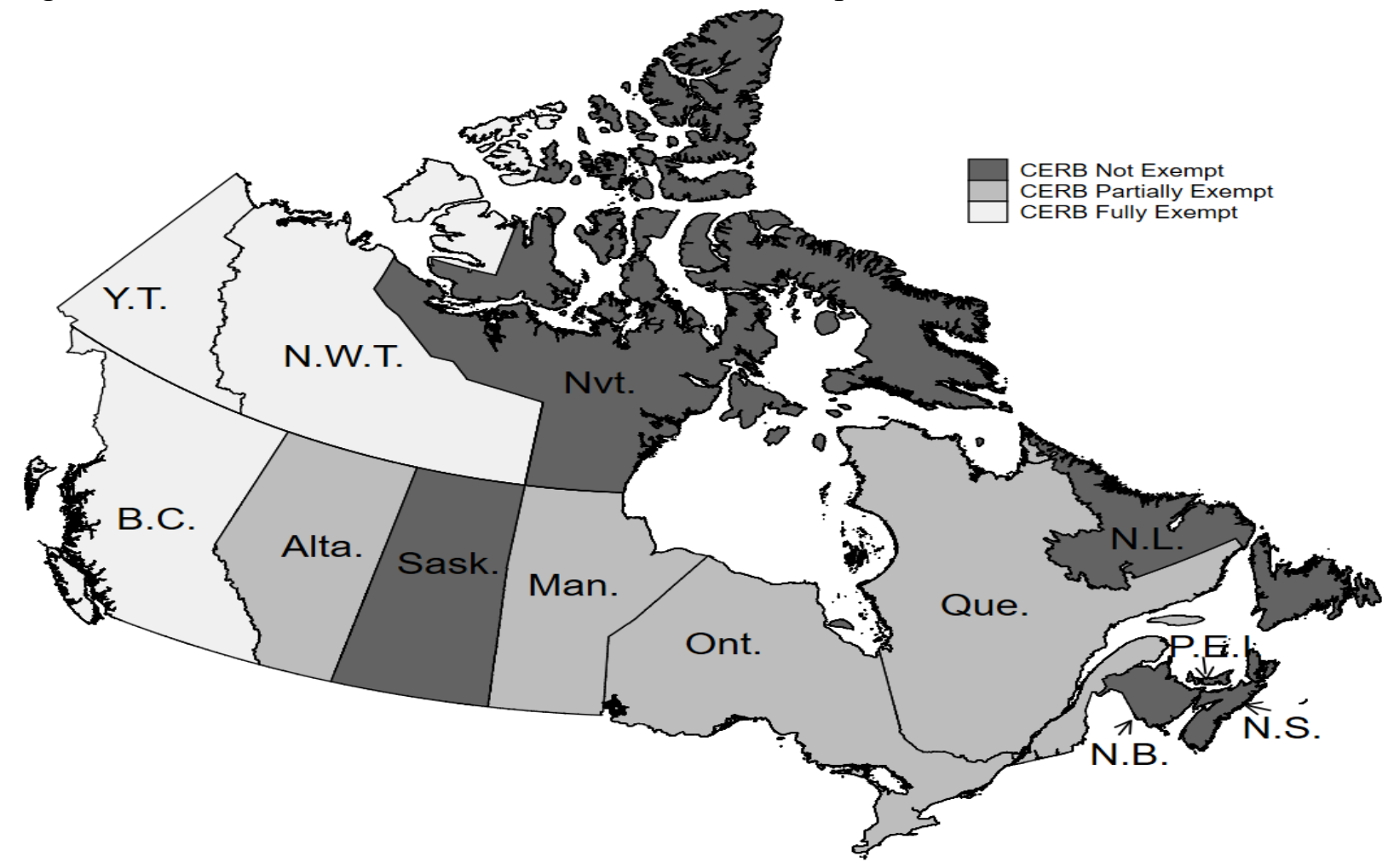

\footnotetext{
${ }^{2}$ Generally, tax benefits are explicitly excluded by regulation from the calculation of qualifying income for the purposes of determining eligibility and benefits of social assistance recipients. Exempt tax benefits include the Canada Child Benefit, provincial child tax credits, the Canada Workers Benefit, the federal GST/HST credit, provincial sales tax credits, and federal and provincial climate tax credits.
} 
This chapter proceeds as follows. We begin by outlining the pertinent details of the CERB program which is followed by detailing how provincial/territorial income assistance programs determine eligibility for and the benefit level of these programs based on types of income. We then integrate the information from these two programs to detail the interactions between income assistance programs and the CERB along with the implications for provincial/territorial income assistance caseloads. We finish by discussing the implications for income assistance programs, specifically, as well as program design more generally.

\section{The Canada Emergency Response Benefit: Program Details}

The Canada Emergency Response Benefit (CERB) was one part of Canada's COVID-19 Economic Response Plan: it was a temporary income support program for workers who had significantly reduced employment earnings due to COVID-19. It was announced on 18 March 2020 by the Prime Minister Justin Trudeau (Prime Minister of Canada 2020b) and legislation received royal assent on 25 March 2020 (Bill C-13 2020) though further amendments to the program were released on 15 April 2020 that shored up some gaps that had been identified (Department of Finance 2020). Applications for the CERB were accepted beginning 6 April 2020 for the previous month (Employment and Social Development Canada 2020a).

To be eligible for the CERB, a person must have been a worker who was at least 15 years of age, a resident of Canada, and who either in 2019 or in the 12 months prior to the CERB application had earned at least \$5,000 from employment, self-employment, EI benefits, or other payments related to pregnancy, new-born children, or adoption (Government of Canada 2020c, s.2). In addition, the worker had to have ceased working for reasons related to COVID-19, and not voluntarily, for at least 14 consecutive days within the four-week period for which they are applying for the benefit for and during that four-week period they could not earn more than $\$ 1,000$ (Government of Canada 2020b, s. 6; 2020e, 2020d).

Those who applied for the CERB received $\$ 2,000$ for each four-week period, regardless of their actual lost income (Government of Canada 2020f). The maximum number of weeks the CERB could be claimed for was initially set at 16 weeks, but it was eventually extended to 24 weeks, and then again to 28 weeks (Prime Minister of Canada 2020a; Employment and Social Development Canada 2020b). An eligible person had to re-apply every four weeks to receive an additional four-week installment of CERB, re-attesting that they met the eligibility conditions. In total, a person could have received up to $\$ 14,000$ in CERB benefits if they applied every four weeks. The CERB was a taxable benefit; however, the tax on the CERB was not deducted at the source meaning that taxes owing on the CERB were assessed upon completion of a 2020 tax return (Golombek 2020).

To deliver payments to Canadians in a fast and simple manner, the CERB application was available jointly through both Canada Revenue Agency (CRA) and Service Canada (through the EI program). The application was online and was short and simple: there were no supporting documents needing to be submitted at time of application to prove eligibility. At the time of application, eligibility was not adjudicated, an adjudication system that has become known as 'trust, then verify' (Robson 2020). This allowed the CRA/Service Canada to process the application and provide a payment within 10 days of the application. When eligibility was verified, those who were not eligible but received a payment had to pay back what they 
erroneously received; however, there will be no penalty (e.g., interest payable) (Government of Canada 2020c, s. 14). As have been well reported, the verification process began in Fall 2020 and ramped up following the filing of 2020 tax returns (Canada Revenue Agency 2020).

As of October 4, 2020, the end date for the CERB program, there were 8.9 million unique applicants to the CERB, with 27.57 million applications received and 27.56 million applications processed. In total, $\$ 81.64$ billion was paid out in CERB benefits (Government of Canada 2020a). This is more than the original cost estimate provided by the Office of the Parliamentary Budget Officer which projected in June 2020 that the CERB would cost $\$ 53.4$ billion (Perrault and Worswick 2020).

\section{Income Assistance Programs}

Each province administers and delivers its own provincial income assistance program. Often called "welfare", these programs provide a monthly cash transfer to persons who have assets and income below a specified threshold. Often, these programs also offer clients access to a host of other in-kind supports, such as health benefits and employment supports. In this section, we specifically examine the income assistance portion of these programs, leaving out a more detailed discussion of other in-kind benefits.

Generally, provinces offer two separate "streams" of income assistance: a temporary stream under which recipients are expected to return to work in the short or medium term, and a disability stream for persons with (verified) disabilities. For both streams, applicants and recipients are required to prove that their qualifying, or "non-exempt", income is below a specified income threshold. The income threshold is the maximum benefit amount that a recipient may receive if eligible for provincial income assistance. The maximum benefit amount differs by province, stream (e.g., temporary assistance or disability assistance), family type, family size, and ability to work. Non-exempt income generally includes all income received minus any permitted deductions and exemptions (which are discussed in more detail blow).

The general idea of income assistance is that, to determine eligibility and the benefit amount, non-exempt income is compared to the maximum benefit amount. If an applicant's/recipient's non-exempt income is less than the maximum benefit amount, the applicant/recipient is eligible for provincial income assistance and their benefit amount is then calculated by subtracting their non-exempt income from the maximum benefit amount they would otherwise be eligible for.

The calculation of both the maximum benefit amount and non-exempt income is complex, relying on sources of income and distinctions of income that are not just found on, for example, an annual tax form. The detailed calculation is shown in Petit and Tedds (2020a) and we summarize their work here.

The complexity arises in that there are two separate categories of non-exempt income, each of which are treated differently in how they factor into the calculation for eligibility and benefit amount, and this varies across jurisdictions. The first category of non-exempt income is nonexempt earned income. To arrive at non-exempt earned income, gross earned income is first adjusted downwards by applying various deductions to arrive a net earned incomed. Deductions include mandatory earnings deductions like EI and CPP contributions that are deducted at source. Net earned income is then further adjusted downwards by applying the earnings 
exemption. Earnings exemptions are calculated by first determining the earnings exemption threshold. Any net earned income below that threshold is exempted and any earnings above the earnings exemption threshold are subjected to a 'phase-out' rate. In other words, any net earned income below the earnings exemption threshold is considered "exempt income" and does not factor into the calculation for the benefit amount. And some net earned income above the earnings exemption threshold is partially exempted while the remaining is non-exempt income and reduces the benefit amount.

For example, suppose that the maximum benefit amount is $\$ 1,000 /$ month, the earnings exemption threshold is $\$ 200 /$ month, and the phase-out rate is $75 \%$. An income assistance recipient earning $\$ 100 /$ month in net earnings would be eligible for income assistance and would receive a monthly benefit amount of $\$ 1,000 /$ month as their non-exempt earnings $(=\$ 100)$ are below the earnings exemption threshold. Comparatively, an income assistance recipient earning $\$ 500 /$ month would also be eligible for income assistance and would receive a monthly benefit amount of $\$ 775(=\$ 1,000-(\$ 500-\$ 200) * 0.75)$. Finally, an income assistance recipient earning $\$ 2,000 /$ month would have non-exempt earnings of $\$ 1,350$. Because $\$ 1,350$ is greater than the maximum benefit amount of $\$ 1,000$, this person would not be eligible for income assistance and receive a monthly benefit amount of $\$ 0$.

The second category of non-exempt income is "other" income. Other income includes anything from dividend income, interest income, investment income, court settlements, spousal and child supports, tax refunds, benefit income, rental income, and so on. To arrive at non-exempt other income, similar to earned income, the first step is to adjust gross other income for deductions to arrive at net other income. Deductions include deductions at source for any of the other income sources along with recognized costs of earning that income, such as essential operating costs related to earning rental income. Then any exemptions are deducted from net other income. Exemptions are specifically included in income assistance legislation and can include things like tax refunds, Canada Child Benefits, and child support payments. These exemptions differ by province and program.

Once both non-exempt earned income and non-exempt other income are calculated, they are added together and compared to the maximum benefit amount to determine eligibility for income assistance and the benefit amount, as discussed above.

\section{Interactions Between CERB and Income Assistance}

We now turn to how this matters for the CERB. As noted above, income assistance recipients are not only expected but also encouraged to work. This means that during the first-wave of the COVID-19 pandemic, some persons who lost employment were income assistance recipients and were potentially eligible for the CERB. Because some income assistance recipients were eligible for the CERB, this made it necessary for each income assistance program to determine how to treat the CERB for eligibility and benefit amount purposes for both applicants and recipients. That is, they had to determine:

- Whether applicants to income assistance who were also receiving the CERB were eligible to enter into income assistance at all. 
- How to classify CERB income for current income assistance recipients. In particular, each provincial income assistance program had to determine if CERB was earned income or other income. If treated as earned income, the CERB would be subject to earnings exemptions already in place. If CERB was designated as "other" income, the provincial income assistance program then had to determine whether there were any associated exemptions.

With respect to the first decision, all provincial/territorial income assistance programs determined that for applicants to income assistance who were receiving the CERB, they would not be eligible for income assistance (at least at the time of CERB receipt).

With respect to the second decision, reviewing income assistance program material from across Canada, different jurisdictions classified the CERB differently. Ultimately, what type of income the CERB was and whether it was exempted was determined by each jurisdiction separately, which then impacted the income assistance eligibility and benefit amount for each jurisdiction differently. Income assistance programs could choose from three routes as discussed above: fully exempt, partially exempt, or not exempt. If the CERB was fully exempt then the CERB had no impact on income assistance eligibility or benefit amounts for current recipients: recipients received both their full income assistance benefit amount and the full CERB amount. If the CERB was partially exempt then the CERB may or may not have affected eligibility for income assistance: whether it did or not is dependent on the relative size of the exemption compared to the size of the maximum benefit amount. If the CERB was not exempt, then persons receiving the CERB had their income assistance benefits reduced to zero-they became ineligible for income assistance.

Table 1 provides details on how each income assistance program by province classified the CERB for their current recipients. British Columbia (B.C.), the Yukon, and the Northwest Territories (NWT) all fully exempted the CERB. That is, the CERB had no impact on income benefits or eligibility of current income assistance recipients. In these jurisdictions, income assistance recipients received the full amount of their income benefits in the months they received CERB (along with the full CERB).

On the other hand, Saskatchewan, Nova Scotia, New Brunswick, Newfoundland, and PEI chose not to exempt CERB. They treated the CERB as other income that was completely non-exempt, From Table 1, for single adults in these jurisdictions, the non-exempt amount of the CERB exceeded the maximum benefit amount, thus all single adult CERB recipients became ineligible for income assistance and had their income benefits reduced to zero.

Finally, Table 1 shows that jurisdictions that partially exempted the CERB had mixed effects on income assistance recipients. Alberta decided to treat CERB income as 'passive business income', which is a form of gross other income for AISH clients, with a partial exemption of $\$ 725 /$ month resulting in a non-exempt amount of $\$ 1,275(=\$ 2,000-\$ 725)$. Because the maximum benefit for single adults receiving AISH is $\$ 1,685$, single adult AISH clients continued to receive $\$ 410 /$ month of their AISH income benefits (along with the full CERB amount). 
Table 1: Treatment of the CERB by Income Assistance Programs by Province and Resultant Effects on Income Assistance Eligibility and Benefits for Single Adult Recipients

\begin{tabular}{|c|c|c|c|c|c|c|c|}
\hline Jurisdiction & Program & $\begin{array}{c}\text { Classification of } \\
\text { CERB }\end{array}$ & $\begin{array}{l}\text { Treatment of CERB } \\
\text { (single adults) }\end{array}$ & $\begin{array}{c}\text { Maximum } \\
\text { monthly benefit } \\
\text { (single adult } \\
\text { without CERB) }\end{array}$ & $\begin{array}{c}\text { Non-Exempt } \\
\text { Amount of } \\
\text { CERB } \\
\text { (monthly) }\end{array}$ & $\begin{array}{l}\text { Effect of CERB receipt } \\
\text { on income assistance } \\
\text { eligibility for current } \\
\text { income assistance } \\
\text { recipients } \\
3\end{array}$ & $\begin{array}{l}\text { Maximum monthly } \\
\text { income assistance } \\
\text { benefit in month when } \\
\text { receiving CERB }\end{array}$ \\
\hline \multirow{2}{*}{$\begin{array}{l}\text { British } \\
\text { Columbia }\end{array}$} & Temporary Assistance & \multirow{2}{*}{$\begin{array}{l}\text { Exempt other } \\
\text { income }\end{array}$} & \multirow{2}{*}{ Fully Exempt } & $\$ 760$ & $\$ 0$ & No effect & $\$ 760$ \\
\hline & Disability Assistance & & & $\$ 1,183.42$ & $\$ 0$ & No effect & $\$ 1,183.42$ \\
\hline \multirow[b]{2}{*}{ Alberta } & Alberta Works (AW) & $\begin{array}{l}\text { Partially exempt } \\
\text { earned income }\end{array}$ & $\begin{array}{c}\$ 230 \text { exempt, } \\
\text { remaining } 25 \% \text { exempt } \\
(75 \% \text { claw back rate })\end{array}$ & $\$ 745$ & $\$ 1,327.50$ & Ineligible & $\$ 0$ \\
\hline & $\begin{array}{l}\text { Assured Income to the } \\
\text { Severely Handicapped } \\
\text { (AISH) }\end{array}$ & $\begin{array}{l}\text { Partially exempt } \\
\text { other income } \\
\text { ("passive business } \\
\text { income") }\end{array}$ & $\begin{array}{l}\$ 300 \text { exempt, } \\
\text { remaining } 25 \% \text { exempt } \\
(75 \% \text { claw back rate })\end{array}$ & $\$ 1,685$ & $\$ 1,275$ & No effect & $\$ 410$ \\
\hline \multirow[b]{2}{*}{ Saskatchewan } & Income Support (SIS) & \multirow{2}{*}{$\begin{array}{l}\text { Non-exempt other } \\
\text { income }\end{array}$} & \multirow{2}{*}{$\begin{array}{l}\text { Deducted 1-for-1 from } \\
\text { benefits }\end{array}$} & $\$ 860$ & $\$ 2,000$ & Ineligible & $\$ 0$ \\
\hline & $\begin{array}{l}\text { Assured Income for } \\
\text { Disability (SAID) }\end{array}$ & & & $\$ 1,064$ & $\$ 2,000$ & Ineligible & $\$ 0$ \\
\hline \multirow[b]{2}{*}{ Manitoba } & EIA & \multirow[b]{2}{*}{$\begin{array}{l}\text { Partially exempt } \\
\text { earned income }\end{array}$} & \multirow{2}{*}{$\begin{array}{l}\$ 200 \text { is exempt, } \\
\text { remaining } 30 \% \text { is } \\
\text { exempt ( } 70 \% \text { claw } \\
\text { back rate). }\end{array}$} & $\$ 771$ & $\$ 1,260$ & Ineligible & $\$ 0$ \\
\hline & EIA (disabilities) & & & $\$ 1,039.50$ & $\$ 1,260$ & Ineligible & $\$ 0$ \\
\hline \multirow[b]{2}{*}{ Ontario } & Ontario Works (OW) & \multirow[b]{2}{*}{$\begin{array}{l}\text { Partially exempt } \\
\text { earned income }\end{array}$} & \multirow{2}{*}{$\begin{array}{l}\text { Amount less than } \\
\text { earnings exemption is } \\
\text { exempt, amounts } \\
\text { above earnings } \\
\text { exemption clawed } \\
\text { back at } 50 \%\end{array}$} & $\$ 733$ & $\$ 900$ & Ineligible & $\$ 0$ \\
\hline & $\begin{array}{l}\text { Ontario Disability } \\
\text { Support Program } \\
\text { (ODSP) }\end{array}$ & & & $\$ 1,169$ & $\$ 900$ & No effect & $\$ 269$ \\
\hline Quebec & Social Assistance & & & $\$ 710$ & $\$ 1,800$ & Ineligible & $\$ 0$ \\
\hline
\end{tabular}

${ }^{3}$ Just because an income assistance recipient became ineligible for the income transfer portion of social assistance (due to CERB), does not necessarily mean they became ineligible for social assistance generally. For example, in Ontario, for social assistance recipients who became ineligible for income assistance, they retained access to health supports also provided to Ontario Works/ODSP recipients. (Durrani 2020) 


\begin{tabular}{|c|c|c|c|c|c|c|c|}
\hline & Sociale Solidarite & $\begin{array}{l}\text { Partially exempt } \\
\text { earned income }\end{array}$ & $\begin{array}{l}\$ 200 \text { is exempt, } \\
\text { remainder will be } \\
\text { clawed back at } 100 \%\end{array}$ & $\$ 1,088$ & $\$ 1,800$ & Ineligible & $\$ 0$ \\
\hline \multirow[t]{2}{*}{ Nova Scotia } & IA & \multirow{2}{*}{$\begin{array}{l}\text { Non-exempt other } \\
\text { income }\end{array}$} & \multirow{2}{*}{$\begin{array}{l}\text { Deducted 1-for-1 from } \\
\text { benefits }\end{array}$} & $\$ 586$ & $\$ 2,000$ & Ineligible & $\$ 0$ \\
\hline & $\begin{array}{l}\text { Disability Support } \\
\text { Program }\end{array}$ & & & $\$ 850$ & $\$ 2,000$ & Ineligible & $\$ 0$ \\
\hline \multirow[t]{2}{*}{ New Brunswick } & Transitional Assistance & \multirow{2}{*}{$\begin{array}{l}\text { Non-exempt other } \\
\text { income }\end{array}$} & \multirow{2}{*}{$\begin{array}{l}\text { Deducted 1-for-1 from } \\
\text { benefits }\end{array}$} & $\$ 564$ & $\$ 2,000$ & Ineligible & $\$ 0$ \\
\hline & Enhanced Assistance & & & $\$ 797$ & $\$ 2,000$ & Ineligible & $\$ 0$ \\
\hline \multirow[t]{2}{*}{ Newfoundland } & Income Support & \multirow{2}{*}{$\begin{array}{l}\text { Non-exempt other } \\
\text { income }\end{array}$} & \multirow{2}{*}{$\begin{array}{l}\text { Deducted 1-for-1 from } \\
\text { benefits }\end{array}$} & $\$ 906$ & $\$ 2,000$ & Ineligible & $\$ 0$ \\
\hline & Income Support (PWD) & & & $\$ 906$ & $\$ 2,000$ & Ineligible & $\$ 0$ \\
\hline \multirow[t]{2}{*}{ PEI } & Social Assistance & \multirow{2}{*}{$\begin{array}{l}\text { Non-exempt other } \\
\text { income }\end{array}$} & \multirow{2}{*}{$\begin{array}{l}\text { Deducted 1-for-1 from } \\
\text { benefits }\end{array}$} & $\$ 988$ & $\$ 2,000$ & Ineligible & $\$ 0$ \\
\hline & AccessAbility Supports & & & $\$ 1,163$ & $\$ 2,000$ & Ineligible & $\$ 0$ \\
\hline Yukon & Social Assistance & $\begin{array}{l}\text { Exempt other } \\
\text { income }\end{array}$ & Fully Exempt & $\begin{array}{c}\$ 1,342 \text { (Nov. - } \\
\text { Mar), \$1,285 } \\
\text { (Apr-May, Oct.), } \\
\$ 1,227 \text { (June- } \\
\text { Sept.) }\end{array}$ & $\$ 0$ & No effect & $\begin{array}{l}\$ 1,285 \text { (Apr-May, } \\
\text { Oct.), } \\
\$ 1,227 \text { (June-Sept.) }\end{array}$ \\
\hline \multirow{2}{*}{$\begin{array}{l}\text { Northwest } \\
\text { Territories }\end{array}$} & IA & \multirow{2}{*}{$\begin{array}{l}\text { Exempt other } \\
\text { income }\end{array}$} & \multirow{2}{*}{ Fully Exempt } & $\$ 1,939$ & $\$ 0$ & No effect & $\$ 1,939$ \\
\hline & IA (PWD) & & & $\$ 2,383$ & $\$ 0$ & No effect & $\$ 2,383$ \\
\hline
\end{tabular}

Notes: all numbers presented here are for single adults who own/rent their place of residence. The first program presented for each province is transitional/temporary assistance for those expected to work. The second program presented for each province is for persons with disabilities. Source: Adapted from Petit and Tedds (2020a), Tables 1 and 2. 
Ontario, Manitoba, Quebec, and Alberta Works all chose to treat CERB income as earned income subject to their earnings exemption. For single adults in these jurisdictions, except for single adult ODSP clients in Ontario, the earnings exemption was such that the maximum benefit was less than the non-exempt CERB income. This means that, for all of these income assistance recipients, they became ineligible for income assistance and had their income benefits reduced to zero if they received the CERB. For example, for single adult income assistance recipients in Manitoba, the earnings exemption was $\$ 740(=\$ 200+(\$ 2000-\$ 200) * 0.3=\$ 740)$ so that non-exempt income from the CERB was $\$ 1,260(=\$ 2,000-\$ 740)$. Because $\$ 1,260$ exceeds the maximum benefit amount for single adults $(=\$ 771)$, these persons received zero income assistance benefits.

\section{Income Assistance Caseloads}

The discussion above posits that to the extent that income assistance recipients in a province earned income, experienced earnings disruptions due to COVID-19, and received the CERB, their eligibility for income assistance was affected differently depending on the jurisdiction in which they lived. This in turn likely affected income assistance caseloads during the COVID-19 pandemic when the CERB was operational. In particular, based on Table 1, we expect to see little change in caseloads in British Columbia, Yukon, and the Northwest Territories, but potentially large negative caseload effects in the other provinces conditional on the proportion of income assistance recipients who work while on benefits.

To investigate this, we examine trends in caseload data from five provinces: B.C., Alberta, Ontario, New Brunswick, and Newfoundland and Labrador. These five provinces were chosen because they were the only five for which income assistance caseload data was obtainable. Fortunately, these five provinces allow us to examine the potential effect of all three of the different treatments of the CERB on caseloads: B.C. fully exempted the CERB, Alberta and Ontario partially exempted the CERB, and New Brunswick and Newfoundland and Labrador did not exempt the CERB. However, before looking at the caseload data, we first look at, in these five provinces, the potential proportion of income assistance recipients that were potentially eligible for the CERB.

Table 2, adapted from Petit and Tedds (2020a), shows the estimated proportion of income assistance recipients in 2020 by province who were potentially eligible for the CERB. It should be noted that this data does not come from the provincial income assistance programs themselves but rather from the Social Policy Simulation Database (SPSD), a statistically representative database of Canadians curated by Statistics Canada: the COVID version was used so that CERB eligibility could be estimated. To create the SPSD data, data from the Canadian Income Survey is used. This data under-reports income assistance recipients and benefits and does not include disability status.

From Table 2, we observe that B.C. and Alberta both have over $20 \%$ of their income assistance recipients who were potentially eligible for the CERB. Ontario has just under $20 \%$ of their income assistance recipients who were potentially eligible for the CERB, and New Brunswick and Newfoundland and Labrador have less than $10 \%$ of their income assistance recipients who were potentially eligible for the CERB. Thus, because New Brunswick and Newfoundland and Labrador have smaller proportions of income assistance recipients potentially eligible for the 
CERB, even though they did not exempt the CERB, we expect to see only a small decline in their caseloads compared to Alberta and Ontario who partially exempted the CERB (effectively making most income assistance recipients receiving the CERB ineligible for income assistance).

Table 2: Estimated Proportion of Income Assistance Recipients Who are Potentially Eligible for the $C E R B$

\begin{tabular}{c|c|c|c} 
Province & $\begin{array}{c}\text { Number of individuals } \\
\text { receiving provincial } \\
\text { income assistance }\end{array}$ & $\begin{array}{c}\text { Number of income } \\
\text { assistance recipients } \\
\text { potentially eligible for } \\
\text { CERB }\end{array}$ & $\begin{array}{c}\text { Percent of income assistance } \\
\text { recipients potentially eligible } \\
\text { for CERB }\end{array}$ \\
\hline BC & 218,789 & 62,234 & $28.44 \%$ \\
\hline AB & 212,480 & 46,911 & $22.08 \%$ \\
\hline ON & 835,823 & 164,882 & $19.73 \%$ \\
\hline NB & 29,481 & 2,866 & $9.72 \%$ \\
\hline NFLD & 20,796 & 919 & $4.42 \%$
\end{tabular}

Source: Adapted from Petit and Tedds (2020a), Table 3.

Figures 2 and 3 plot the percentage change in income assistance caseloads relative to April 2020 (the first month CERB was collected) for the five provinces noted above. Figure 2 includes temporary assistance programs for those expected to work. Figure 3 includes income assistance programs for persons with disabilities who are not expected to work but who are nevertheless supported in employment. There are two notes to make. First, Newfoundland and Labrador temporary assistance and disability assistance caseloads are reported together. Thus, we include Newfoundland and Labrador caseload only in Figure 2, noting that the data for temporary and disability assistance are combined. Second, these figures are for all family types, not just single adults (unlike Table 1).

From these figures, we see varying patterns of changes in caseload after the receipt of CERB started. From Figure 2, we see that after the receipt of CERB began, temporary assistance caseloads decreased. In both Alberta and Ontario where CERB was partially exempt (but had the effect of making single adults ineligible for income assistance nevertheless), we see the largest drops in the temporary assistance caseloads. The caseload for Alberta works declined by $25 \%$ between April 2020 and September 2020, from 61,060 cases to 45,725 cases. Likewise, the caseload for Ontario Works fell by 15\% between April 2020 and September 2020 from 251,315 cases to 212,774 cases.

New Brunswick and Newfoundland and Labrador temporary assistance caseloads saw the next largest decline in caseloads. Both of these provincial programs did not exempt the CERB. New Brunswick Transitional Benefit caseload fell by 12\% between April 2020 and December 2020 and Newfoundland's (total) caseload fell by 8\% between April 2020 and November 2020. 
Figure 2: Percent Change in Temporary Assistance Caseloads Compared to April 2020, Deseasonalized data
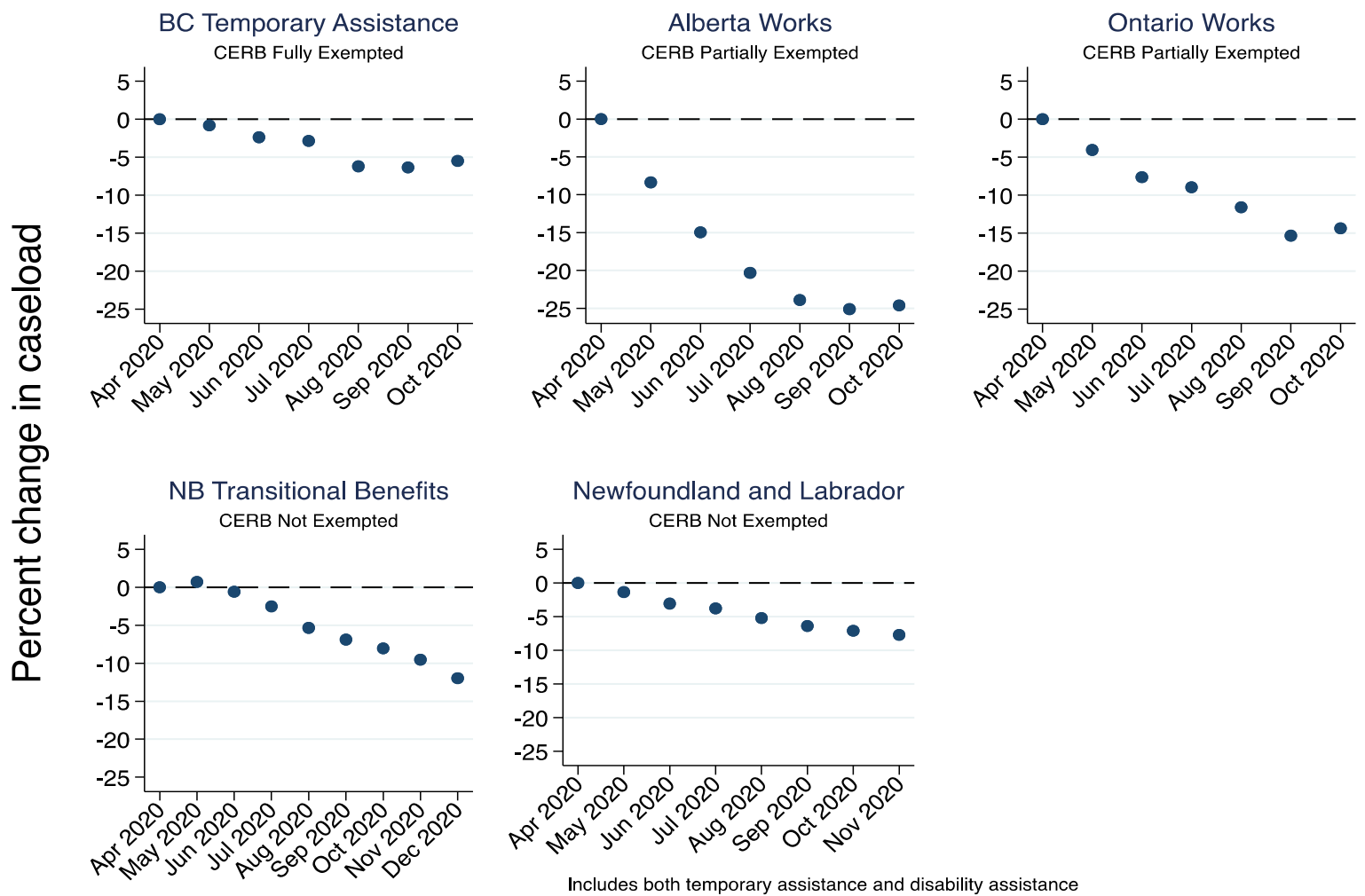

Note: data deseasonalized by authors.

Sources: BC Ministry of Social Development and Poverty Reduction (2021); Government of Alberta Open Data (2021); Ontario Ministry of Children, Community, and Social Services (2021); New Brunswick Ministry of Social Development (n.d.); Newfoundland and Labrador Ministry of Immigration, Skills, and Labour (n.d.).

Finally, B.C.'s Temporary Assistance caseload fell by the least amount following receipt of the CERB. Recall that B.C. chose to fully exempt the CERB. The BC Temporary Assistance caseload fell by 6\% between April 2020 and September 2020, from 49,361 cases to 46,228 cases.

In Figure 3, there is very little change in disability assistance caseloads between April 2020 and October 2020. The largest decline was in Ontario for ODSP which fell by $1.5 \%$ from April 2020 to August 2020.

The fact that disability assistance caseloads did not see a large decline is not surprising. From Table 1, persons receiving disability assistance in B.C., Alberta, and Ontario who also received the CERB remained eligible for and continued to receive disability assistance. We also posit that because of the rule making CERB recipients who were not currently income assistance recipients ineligible for income assistance, this rule had a larger impact on temporary assistance than on disability assistance. Disability assistance is a long-term program, with recipients expected to continue receiving disability assistance for long periods of time, if not until they reach the age of 
Figure 3: Percent Change in Disability Assistance Caseloads Compared to April 2020, Deseasonalized data

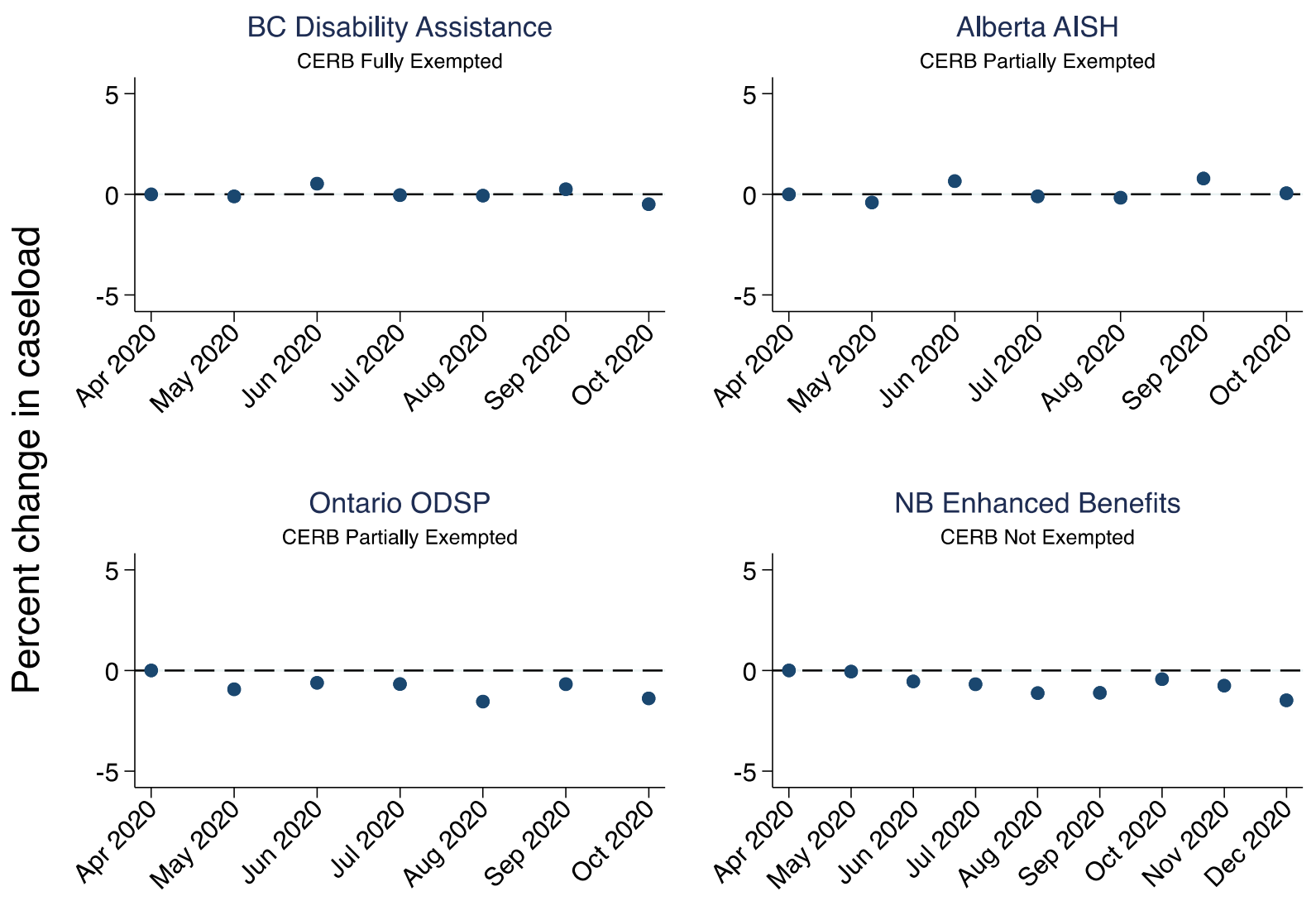

Note: data deseasonalized by authors.

Sources: BC Ministry of Social Development and Poverty Reduction (2021); Government of Alberta Open Data (2021); Ontario Ministry of Children, Community, and Social Services (2021); New Brunswick Ministry of Social Development (n.d.).

65 (when they transition onto OAS/GIS), compared to temporary assistance: in a given month, there are less in-flows into disability assistance programs than into temporary assistance programs. Thus, the receipt and treatment of CERB had a smaller effect on both exits and entry into disability assistance compared to temporary assistance.

The decline observed in temporary assistance caseloads is also not surprising given how CERB interacted with temporary assistance programs. In Alberta and Ontario who partially exempted the CERB, this partial exemption would have reduced entries into temporary assistance and increased exits out of temporary assistance given that CERB receipt made Alberta Works and Ontario Works applicants and recipients ineligible for temporary assistance. Comparatively in B.C. where the CERB was fully exempt for current temporary assistance recipients, CERB should not have had much of an effect on exits, instead, it would have decreased entries. Using the data we have access to, we do see that in B.C. that there was a large decline in temporary assistance entries after the implementation of the CERB; however, there is also a slight increase in exits. We posit the increase in exists in B.C. was due to a stronger labour market in the 
province due to the relaxing of COVID-19 restrictions that happened in June as well as the presence of the CERB, which continued to provide a safety net for those exiting income assistance and who might experience labour market disruptions if and when the pandemic reversed course.

Finally, in both New Brunswick and Newfoundland and Labrador where the CERB was not exempted, there was only moderate declines in temporary assistance caseloads. Without more detailed data, we can only provide conjectures as to why the decline in caseload in New Brunswick and Newfoundland and Labrador was only moderate even though they did not exempt the CERB. The most likely reason is that, as Table 2 suggests, only a small proportion of income assistance recipients in New Brunswick and Newfoundland and Labrador were potentially eligible for the CERB. Therefore, it is possible that less income assistance recipients qualified for the CERB in New Brunswick and Newfoundland and Labrador than in provinces like Alberta and Ontario, resulting in CERB having a smaller effect on caseload exits in New Brunswick and Newfoundland and Labrador than in Alberta and Ontario. A second plausible explanation as to why the change in caseload in New Brunswick and Newfoundland and Labrador was only moderate is that the Newfoundland and Labrador caseload data does not distinguish between temporary assistance and disability assistance. Since both streams are aggregated, it may be the case that for the Newfoundland and Labrador data, the decline in the temporary assistance caseload is being offset by a smaller decline in the disability assistance caseload.

It is unlikely that the only moderate declines in temporary assistance caseloads in New Brunswick and Newfoundland and Labrador was due to lower unemployment rates, less stringent lockdown measures or lower CERB take-up - any of which may have reduced the takeup of CERB among existing and potential social assistance recipients. New Brunswick and Newfoundland and Labrador both had larger drops in employment than any of the other provinces examined and New Brunswick had more stringent lockdown measures than both Ontario and Alberta at some points in time (Sim and Breton 2020). In fact, both of these trends suggest that more persons in New Brunswick and Newfoundland and Labrador should have taken up the CERB, including social assistance recipients, compared to Ontario and Alberta. However, when examining the CERB data, the number of unique recipients of CERB per working age population is relatively similar for New Brunswick and Newfoundland and Labrador compared to all other jurisdictions.

\section{Discussion}

Why was the CERB was treated differently across different jurisdictions and programs? That is, why did some income assistance programs treat CERB as employment income (with the corresponding earnings exemption and claw back rates), others treat it as "other income," and yet others treat it as exempted other income? We proffer that, because of the swiftness with which the CERB was put into place, there was very little technical guidance as to what the CERB was: the federal government did not clarify whether the CERB was a replacement for earned (employment) income, a replacement for deferred earnings programs (e.g., Employment Insurance that was unable to cope with the surge in applications during the pandemic), or an income benefit program, paid out of general revenue to supplement low income. 
There are a number of observations that can be made that result from the lack of clarity of the CERB. First, as we have implied elsewhere but which we now state directly, because the CERB was not clearly defined and thus treated differently across different income assistance programs, income assistance recipients were treated differently depending on where they lived. A recipient of Alberta Works and the CERB living in Canmore Alberta would be have been cut off of Alberta Works whereas a recipient of BC Temporary Assistance and the CERB living in Golden $\mathrm{BC}$, less than three hours away from the Alberta Works recipient, would continue to receive both Temporary Assistance and the CERB. There does not appear to be justification for this difference in treatment. Indeed, a Manitoba Court of Appeal judge appears to agree that there is a lack of justification for this difference agreement in granting leave to appeal a case involving the clawback of the CERB from a person receiving income assistance in Manitoba (Cann v Director, Fort Garry/River Heights, 2020 MBCA 101 (CanLII) 2020).

Second, because the CERB was not clearly defined, some provinces choose to offset some of their income assistance costs and shift them to the federal government, meaning the CERB program was used as a provincial fiscal policy tool rather than a social policy tool. The additional distributional shift was a (small) cost saving mechanism for the provinces at a (large individual) cost for some of the most vulnerable persons in the province: it was a signal of how the provincial governments were approaching a health emergency that imposed a devasting economic toll on people.

Finally, more broadly, this chapter demonstrates that a large reason for the complexity in the web of income and social support programs that are offered to Canadians is that new programs are often implemented without considering interactions with the existing suite of cross-government or cross-ministry programs. This can lead to unfortunate and unintended outcomes that actually reduce the effectiveness not only of the individual programs but also the suite of programs: it can reduce the ability of programs to reach their intended targets and can reduce the ability of government to achieve important goals such as poverty reduction and supporting transitions into paid work.

In this case, the implementation of CERB legislation did not address its interactions with provincial/territorial income assistance programs. This jointly reduced the effectiveness of the CERB and income assistance in providing much-needed income supports to the most vulnerable populations during the pandemic.

What broad lesson can be taken from this experience to improve policy outcomes in the future? Federal-provincial-territorial negotiations regarding how the subnational jurisdictions will treat federal income benefits in their programs has, to date, been approached in a one-off fashion, program by program. For example, before the implementation of the $\mathrm{CCB}$, provinces were consulted by the federal government. During negotiations, the governments collaborated to avoid any "negative interactions" (McGregor 2016). Due to the required speed in the roll-out of the CERB, these types of negotiations were not able to be satisfactorily completed for the CERB. When normal closed-door negotiations fell through, the federal minister of employment, workforce development, and disability inclusion, Carla Qualtrough, requested through the media after the CERB was implemented that provincial income assistance programs not penalize those receiving the CERB and exempt the CERB in the same way the CCB is exempt (Monsebraaten 
2020). Clearly, this request was not heeded by many provincial/territorial income assistance programs.

A different approach would be to negotiate a general framework that would be followed in all circumstances for all cash transfer programs. This framework would establish when and under what conditions income would be considered benefit income (akin to the CCB) and thus be fully exempted from income assistance income tests or earned income and thus partially exempt from income tests or other income (akin to Employment Insurance) and thus be not exempt from income tests. The federal government would then use this framework to set the type of income in the enabling legislation for the program. Having such a framework established and agreed upon a priori could then ensure in situations where time does not allow for detailed negotiations or political posturing can derail objectives, existing and new programs can be designed and implemented as intended, according to their objectives, and delivered consistently across Canada.

In terms of administrative institutions in Canada that are intended to meet social need, it is important that policy and decision makers remember that social assistance recipients are amongst societies most vulnerable. Some (e.g., Boessenkool 2020) have argued that social assistance recipients should be treated no differently than any other low-income Canadians, but that guidance ignores the reality; social assistance recipients are different. Social assistance recipients are not just experiencing low income. In order to be assessed eligible for income assistance, they have had to satisfy a punishing set of eligibility criteria established for the sole purpose of keeping people out of the program. These eligibility criteria include proving they have very limited to no cash or other assets, no means of family support, and that they have exhausted all viable employment opportunities. Further, while many believe social assistance is used as an emergency stop-gap for individuals experiencing a temporary job separation, provincial caseload trends show that social assistance is more and more becoming a program for persons with disabilities and long-term barriers to employment. Petit and Tedds (2020b) show that in B.C., persons with disabilities plus persons with persistent and multiple barriers to employment make up over $73 \%$ of the total social assistance caseload. Those with persistent and multiple barriers to employment include those with mental health conditions and addictions, and those escaping intimate partner violence who have suffered a traumatic brain injury - factors which themselves should be considered disabilities.

Policy decisions, regardless of whether they are made by the federal government or provincial/territorial governments, that affect social assistance recipients should reflect this reality. Yet too often, as evidenced by the decision taken by many provinces regarding the CERB, social assistance recipients are treated with immense stigma. Voluminous research (see Petit and Tedds $2021 \mathrm{~b}$ for a summary) shows that this stigma not only prevents those in need from accessing the support they need, but it also results in program conditions that trap recipients in poverty.

The differential decision of how to treat the CERB for the purposes of provincial income assistance is likely to have long-run impacts on social assistance caseloads. The CERB was an opportunity to provide to those receiving income assistance benefits a chance to save money. The building up of assets is a necessary pre-condition for self-sufficiency (Robson 2008) and 
may reduce dependency on income assistance, allowing recipients to permanently leave income assistance. Thus, the jurisdictions that exempted the CERB may see more reduced dependency on income assistance amongst affected recipients compared to jurisdictions that chose to partially or not exempt the CERB. Policy makers across Canada should carefully watch this trend and use the resulting evidence to change income support programs. 


\section{References}

BC Ministry of Social Development and Poverty Reduction. 2021. "BC Employment and Assistance Program." Accessed January 2021. https://catalogue.data.gov.bc.ca/dataset/bcemployment-and-assistance-program.

Bill C-13. 2020. An Act respecting certain measures in response to COVID-19.

Boessenkool, Ken. 2020. Three ways to treat CERB in social assistance. C.D. Howe Institute. https://www.cdhowe.org/intelligence-memos/ken-boessenkool---three-ways-treat-cerbsocial-assistance.

Canada Revenue Agency. 2020. "Validation of applications: CERB with CRA." Last Modified 2020-10-08. https://www.canada.ca/en/revenue-agency/services/benefits/apply-for-cerbwith-cra/keep-payment.html.

Cann v Director, Fort Garry/River Heights, 2020 MBCA 101 (CanLII). 2020. CanLII.

Department of Finance, Canada, 2020, "Expanding access to the Canada Emergency Response Benefit and proposing a new wage boost for essential workers," https://www.canada.ca/en/department-finance/news/2020/04/expanding-access-to-thecanada-emergency-response-benefit-and-proposing-a-new-wage-boost-for-essentialworkers.html.

Durrani, Tebasum. April 24, 2020 2020. Low-income Ontarians facing partial claw back of federal assistance during COVID-19. healthydebate. https://healthydebate.ca/2020/04/topic/ontario-low-income-cerb-covid.

Employment and Social Development Canada, 2020a, "Canada emergency Response Benefit to Launch on April 6," https://www.canada.ca/en/employment-socialdevelopment/news/2020/04/canada-emergency-response-benefit-to-launch-on-april6.html.

---, August 20, 2020, 2020b, "Government of Canada Announces Plan to Help Support Canadians Through the Next Phase of the Recovery," https://www.canada.ca/en/employment-social-development/news/2020/08/governmentof-canada-announces-plan-to-help-support-canadians-through-the-next-phase-of-therecovery.html.

Golombek, Jamie. 2020. Calculating the tax you may owe on your COVID-19 benefits. CIBC. https://www.cibc.com/content/dam/personal banking/advice centre/tax-savings/covidbenefits-tax-en.pdf.

Government of Alberta Open Data. 2021. "Income Support Caseload." Accessed January 2021. https://open.alberta.ca/opendata/income-support-caseload-alberta.

Government of Canada. 2020a. "Canada Emergency Response Benefit Statistics." Last Modified December 23, 2020. https://www.canada.ca/en/services/benefits/ei/claims-report.html.

---. 2020b. Covid-19 Emergency Response Act. In S.C. 2020, c.5, edited by Government of Canada.

---. 2020c. COVID-19 Emergency Response Act, S.C. 2020 c. 5. In S.C. 2020, c.5, edited by Government of Canada.

---. 2020d. Income Support Payment (Excluded Nominal Income) Regulations, SOR/2020-90.

---. 2020e. Income Support Payment (Excluded Nominal Income) Regulations, SOR/2020-90.

---. 2020f. Income Support Payment Amount Regulations, SOR/2020-62.

Governor General of Canada. 2020. A Strong and More Resilient Canada: Speech From the Throne. 
McGregor, Janyce. 2016. "Canada Child benefit seen as fighting poverty - as long as provinces co-operate." $C B C, 2016$. Accessed January 13, 2021.

https://www.cbc.ca/news/politics/ccb-social-assistance-clawback-provinces-campaign2000-1.3675873.

Monsebraaten, Laurie. 2020. "Ottawa to the provinces: Don't claw back CERB for workers on social assistance." Toronto Star, 2020. Accessed January 13, 2021.

https://www.toronto.com/news-story/9941452-ottawa-to-the-provinces-don-t-claw-backcerb-for-workers-on-social-assistance/.

New Brunswick Ministry of Social Development. n.d. "Social Assistance Caseload and Recipients."

https://www2.gnb.ca/content/gnb/en/departments/social development/statistics/social as sistance caseload and recipients.html.

Newfoundland and Labrador Ministry of Immigration Skills and Labour. n.d. "Income Support Caseload Statistics." Accessed January 2021. https://www.gov.nl.ca/isl/incomesupportcase/.

Ontario Ministry of Children Community and Social Services. 2021. Social Assistance Recipients in Ontario.

Perrault, Louis, and Aidan Worswick. 2020. Legislative Costing Note: Canada Emergency Response Benefit - Update. Office of the Parliamentary Budget Officer. https://www.pbodpb.gc.ca/web/default/files/Documents/LEG/LEG-2021-030-S/LEG-2021-030-S en.pdf.

Petit, Gillian, and Lindsay M. Tedds. 2020a. "The Effect of Differences in Treatment of the Canada Emergency Response Benefit across Provincial and Territorial Income Assistance Programs." Canadian Public Policy 46 (S1): S29-S43. https://doi.org/10.3138/cpp.2020-054.

---. $2020 \mathrm{~b}$.

---. 2021a. "COVID-19 \& Trends in Income Assistance Caseloads." The School of Public Policy Publications 14: 1-2. https://doi.org/https://doi.org/10.11575/sppp.v14i https://www.policyschool.ca/wp-content/uploads/2021/02/FPT-covid-socialassistance.pdf.

---. $2021 b$.

Prime Minister of Canada, Justin Trudeau. 2020a. "Prime Minister announces extension of the Canada Emergency Response Benefit." Last Modified June 16, 2020.

https://pm.gc.ca/en/news/news-releases/2020/06/16/prime-minister-announces-extensioncanada-emergency-response-benefit.

---, 2020b, "Prime Minister announces more support for workers and businesses through Canada's COVID-19 Economic Response Plan," https://pm.gc.ca/en/news/newsreleases/2020/03/18/prime-minister-announces-more-support-workers-and-businessesthrough.

Robson, Jennifer. 2008. Wealth, Low-Wage Work and Welfare: The Unintended Costs of Provincial Needs-tests. Social and Enterprise Development Innovations. https://prospercanada.org/getattachment/b704caf8-7bbb-4aca-b71087c67261b18f/Wealth,-Low-Wage-Work-and-Welfare-The-Unintended-C.aspx.

---. 2020. "Radical Incrementalism and Trust in the Citizen: Income Security in Canada in the Time of COVID-19." Canadian Public Policy. https://doi.org/10.3138/cpp.2020-080. https://www.utpjournals.press/doi/full/10.3138/cpp.2020-080. 
Sim, Paisley, and Charles Breton, 2020, "In the Canadian federation, pandemic response is hyper-local," https://policyoptions.irpp.org/magazines/november-2020/in-the-canadianfederation-pandemic-response-is-hyper-local/. 